Mandu, I. \& Zaffuto, S. F. (1958). J. gen. Microbiol. 18, 13-15

\title{
Serological Evidence for a Specific Clostridium histolyticum Gelatinase
}

\author{
BY INES MANDL AND S. F. ZAFFUTO \\ Departments of Biochemistry and Microbiology, College of Physicians and \\ Surgeons, Columbia University, New York
}

SUMMARY: Evidence is presented that a specific gelatinolytic enzyme besides collagenase is present in purified Clostridium histolyticum collagenase preparations. This means that collagenase itself need not be able to digest gelatin but it does not exclude the possibility.

The purest collagenase available to date (DeBellis, Mandl, MacLennan \& Howes, 1954) is free of non-specific proteolytic activity and active only against collagen and collagen degradation products (azocoll, gelatin). The question whether these activities are due to the same enzyme, i.e. whether collagenase will break down gelatin as well as collagen is still unsolved. It is possible that a series of reactions catalysed by distinct enzymes is involved but that our analytical procedures are inadequate for the detection of the primary effect of collagenase. This may involve simple breaking of hydrogen bonds as in urea treatment which results in denatured collagen susceptible to enzymes such as trypsin. However, the entire collagenase system differs from such proteinases by its specificity and complete lack of reaction with other proteins such as casein or haemoglobin as well as numerous synthetic substrates tested in this laboratory (Mandl, Zipper \& Ferguson, 1957).

The presence of a specific gelatinase was first suspected when fractionation of crude collagenase (DeBellis $\mathrm{el} \mathrm{al.} \mathrm{1954)}$ ) invariably showed the fraction with maximum collagenase activity preceding the corresponding azocoll maximum. If the collagenase were the only enzyme in this region capable of attacking azocoll, the maxima should coincide. Furthermore, the ratio of collagenase to azocoll activity is not the same in different preparations and the concentrations of certain ions (Co, Ni) needed to inhibit activity of any one preparation differ with the substrate hydrolysed (see Table 1).

Ogle \& Logan (1956) have also advanced evidence for the presence of a distinct gelatinase in the collagenase system.

Gelatin or azocoll attack by the preparations investigated could not be ascribed to other known proteinases (MacLennan, Mandl \& Howes, 1958; DeBellis et al. 1954) since the fractions were free of $\delta$-proteinase and $\gamma$ - (or $\epsilon-)$ proteinase would not be active in the absence of cysteine.

In the belief that serological tests would be more conclusive the following set of experiments was set up: varying dilutions of six sera kindly supplied by Professor Oakley of Leeds University and used for the detection of other specific enzymes (MacLennan et al. 1958; Oakley \& Warrack, 1950) were incubated for half-hour periods with equal volumes of $0.1 \%$ solutions of an enzyme fraction rich in collagenase and free of $\delta$-proteinase prepared according 
Table 1. Molar concentrations of different metal ions completely inhibiting action of $0.1 \mathrm{mg}$ enzyme $\mathrm{L} 139_{p} 28$ fraction $\mathrm{III}$ [26-30\% $\left(\mathrm{NH}_{4}\right)_{2} \mathrm{SO}_{4}$ conc.]

\begin{tabular}{cccc} 
& \multicolumn{3}{c}{ Substrates } \\
Metal ion & $\begin{array}{c}\text { Collagen } \\
(10 \mathrm{mg} / 2.5 \mathrm{ml} .)\end{array}$ & $\begin{array}{c}\text { Azocoll } \\
(50 \mathrm{mg} . / 10 \mathrm{ml} .)\end{array}$ & $\begin{array}{c}\text { Gelatin } \\
(30 \mathrm{mg} . / 2 \mathrm{ml} .)\end{array}$ \\
$\mathrm{Ca}$ & $>0.5$ & $10^{-1}$ & $>1$ \\
$\mathrm{Co}$ & 0.5 & $10^{-3}$ & $>0.5$ \\
$\mathrm{Fe}^{++}$ & $10^{-3}$ & $10^{-3}$ & 0.5 \\
$\mathrm{Fe}+++$ & $10^{-3}$ & $10^{-3}$ & $10^{-2}$ \\
$\mathrm{Mg}$ & 0.5 & $10^{-1}$ & $>1$ \\
$\mathrm{Mn}$ & $0 \cdot 5$ & $10^{-2}$ & $>0.5$ \\
$\mathrm{Ni}$ & $10^{-3}$ & $10^{-3}$ & $>0.5$ \\
$\mathrm{~Pb}$ & $10^{-3}$ & $10^{-3}$ & $10^{-1}$ \\
$\mathrm{Zn}$ & $10^{-3}$ & $10^{-3}$ & $10^{-1}$
\end{tabular}

Table 2. Relative serum concentrations completely inhibiting action of enzyme No. L $139_{p} 28$ fraction III [26-30\% $\left(\mathrm{NH}_{4}\right)_{2} \mathrm{SO}_{4}$ conc.]

\begin{tabular}{|c|c|c|c|}
\hline \multirow[b]{2}{*}{ Serum no. } & \multicolumn{3}{|c|}{ Substrate } \\
\hline & $\begin{array}{c}\text { Collagen } \\
(10 \mathrm{mg} . / 5 \mathrm{ml} .)\end{array}$ & $\begin{array}{c}\text { Azocoll } \\
(10 \mathrm{mg} \cdot / 5 \mathrm{ml} .)\end{array}$ & $\begin{array}{c}\text { Gelatin } \\
(30 \mathrm{mg} . / \mathrm{ml} .)\end{array}$ \\
\hline RR2001 & 100 & 100 & 100 \\
\hline RR 2005 & 300 & 200 & 130 \\
\hline RR 2008 & 300 & 400 & 155 \\
\hline RR 2035 & 200 & 200 & 155 \\
\hline RR 8003 & 100 & 300 & 210 \\
\hline RR8006 & 150 & 200 & 130 \\
\hline
\end{tabular}

to the method of DeBellis et al. (1954), The resulting complexes were then allowed to react with the substrates under investigation-collagen, azocoll and gelatin-and the lowest serum dilutions which completely inhibited the breakdown of these substrates compared. Azocoll and collagen tests were performed as previously described (Mandl, MacLennan \& Howes, 1953; MacLennan et al. 1958). Gelatinase was tested by its action on $3 \%$ gelatin in $0 \cdot 1 \mathrm{M}$-phosphate buffer $\mathrm{pH} 7 \cdot 1$. In all tests with added metal ions (Table 1) veronal + acetate buffer $\mathrm{pH} \mathbf{7 \cdot 4}$ (Michaelis, 1931) was used instead of phosphate. After incubation at $37^{\circ}$ for $3 \mathrm{hr}$. the tubes were placed in the refrigerator and the end-point determined visually as the lowest serum concentration preventing liquefaction. Relative results are shown in Table 2, arbitrarily assigning a value of 100 to all anti-enzyme concentrations of serum no. 2001.

Relative inhibiting concentrations for azocoll and collagen hydrolysis largely agree with those found by MacLennan el al. (1958) for crude collagenase, but there are some differences, i.e. relative values of serum RR 8003 for collagen and RR2035 for azocoll, between the crude collagenase and the purified fraction used in this study. Anti-collagenase values with collagen as substrate are essentially identical with the values of Oakley \& Warrack (1950). With azocoll as substrate, values differ for some sera, indicating the presence of another enzyme, besides collagenase, capable of attacking this substrate.

The newer results with gelatin as substrate show that some other enzyme besides that acting on collagen is present and active against gelatin, although 
the possibility that the collagenase ( $\beta$-toxin) also acts against gelatin cannot be excluded.

Table $\mathbf{3}$ shows a comparison between the end-points against azocoll and gelatin substrate of a purified $\delta$-proteinase fraction, free from collagenase. Serum no. 2001 has again been arbitrarily assigned relative values of 100 .

Table 3. Relative serum concentrations completely inhibiting action of enzyme No. L 139 28 fraction $I$ [0-22\% $\left(\mathrm{NH}_{4}\right)_{2} \mathrm{SO}_{4}$ conc. $]$

$\begin{array}{lcc}\text { Serum no. } & \overbrace{\text { Azocoll }}^{\text {Substrate }} & \begin{array}{c}\text { Gelatin } \\ (10 \mathrm{mg} / / 5 \mathrm{ml} .)\end{array} \\ \text { RR2001 } & 100 & 100 \\ \text { RR2005 } & 50 & 75 \\ \text { RR2008 } & 200 & 115 \\ \text { RR2035 } & 200 & 170 \\ \text { RR8003 } & 100 & 100 \\ \text { RR8006 } & 100 & 115\end{array}$

The end-points agree with the $\delta$ values found with the differently prepared and far less active proteinase described by MacLennan et al. (1958). They are the same against both substrates within experimental error and distinct from those shown in Table 2. The gelatinase activity of this fraction can therefore be ascribed to $\delta$-proteinase and is distinct from the new gelatinase reported here.

The findings reported increase the minimum number of proteolytic enzymes present in Clostridium histolyticum filtrates to seven: $\delta$-proteinase (cysteine inhibited), $\gamma$-proteinase (cysteine activated), $\beta$-collagenase, amidase-esterase $(\epsilon$ ?), at least two peptidases (Mandl, Ferguson \& Zaffuto, 1957) and the new gelatinase here reported. They also show that a specific gelatinase is associated with the purest collagenase available. Collagenase itself may or may not attack gelatin.

This work was supported in part by a grant from the United States Public Health Service, National Institute for Arthritis and Metabolic Diseases.

\section{REFERENCES}

DeBeluis, R. H., Mandi, I., Maclennan, J. D. \& Howes, E. L. (1954). Separation of proteolytic enzymes of $\mathrm{Cl}$. histolyticum. Nature, Lond. 174, 1191.

Maclennan, J. D., Mande, I. \& Howes, E. L. (1958). New proteolytic enzymes from $\mathrm{Cl}$. histolyticum filtrates. J. gen. Microbiol. 18, 1.

Mandl, I., Ferguson, L. T. \& Zaffuto, S. F. (1957). Exopeptidases of Cl. histolyticum. Arch. Biochem. Biophys. 69, 565.

Mandi, I., MacLennan, J. D. \& Howes, E. L. (1953). Isolation and characterization of proteinase and collagenase from Cl. histolyticum. J.clin. Invest. 32, 1323.

Mandi, I., Zipper, H. \& Ferguson, L. T. (1957). Cl. histolyticum collagenase: its purification and properties. Arch. Biochem. Biophys. (in the Press).

Michaelis, L. (1931). Der Acetat-Veronal Puffer. Biochem. Z. 234, 139.

OAKIEY, C. L. \& WARrack, H. J. (1950). The alpha, beta and gamma antigens of Cl. histolyticum (Weinberg \& Séguin, 1916). J. gen. Microbiol. 4, 365.

Ogle, J. D. \& Logan, M. A. (1956). Gelatinase action of Cl. histolyticum. Fed. Proc. 15, 323. 